\title{
Exploration and Effectiveness of Trichoderma sp. from Jember and Trenggalek, East Java, Indonesia Cacao Plantation as A Biological Control of Phytophthora palmivora
}

\author{
Henik Sukorini ${ }^{1}$, Feby Wirasdenty Aigahayunindy ${ }^{1}$, Erfan Dani Septia ${ }^{2, *}$, \\ and Netnapis Khewkhom ${ }^{3}$ \\ ${ }^{1}$ Department of Agrotechnology, Faculty of Agriculture and Animal Science, \\ University of Muhammadiyah Malang, Jl. Raya Tlogomas no 246 Malang 65145, \\ East Java, Indonesia \\ ${ }^{2}$ The Center of Biotechnology Development, University of Muhammadiyah Malang, \\ J1. Raya Tlogomas no 246 Malang 65145, East Java, Indonesia \\ ${ }^{3}$ Department of Plant Pathology, Faculty of Agriculture, Kasetsart University, \\ 50 Thanon Ngamwongwan, Lat Yao, Chatuchak, Bangkok 10900, Thailand
}

\begin{abstract}
Fruit rot disease is very damaging to cacao pods, which is caused by Phytoptora palmivora. The attack rate of $P$. palmivora varies. In Java, losses due to this disease reduce yields by $90 \%$. P . palmivora is a soil-borne pathogen. It is currently included in the Kingdom Chromista. Control with fungicides is not successful at this time, the alternatives is biologis control with Trichoderma sp. This research used a Completely Randomized Design (CRD) which was arranged in factorial with two factors. The first factor was Trichoderma sp. the second factor was $P$. palmivora. All treatment combinations were repeated three times. Trichoderma sp. antagonist test to $P$. palmivora was analyzed using Analysis of Variance (ANOVA) and then further tested using a $5 \%$ BNJ. Trichoderma sp. origin from Jember and Trenggalek districts, East Java, Indonesia were able to act as antagonists against $P$. palmivora with the highest inhibitory of $78 \%$. In comparison, the lowest inhibitory was $70 \%$ of isolates from Jember district, East java, Indoe. Characteristics of Trichoderma sp. The origin of Trenggalek Regency and Jember Regency, East Java, Indonesia in inhibiting the growth of $P$. palmivora has the same species, namely Trichoderma harzianum.
\end{abstract}

Key words: Biologis control, environmentally friendly, fruit rot, increase cacao tree productivity, Theobroma cacao $\mathrm{L}$.

\section{Introduction}

Cacao (Theobroma cacao L.) is one of the primary export commodities of Indonesia where over the past $5 \mathrm{yr}$, Indonesia has provided about 1951270 ha area of cacao plants. Unfortunately, its productivity level in the same period results in only around $655 \mathrm{~kg} \mathrm{ha}^{-1}$. In comparison, the productivity of cacao in Malaysia reaches about $1800 \mathrm{~kg} \mathrm{ha}^{-1}$, around 800 $\mathrm{kg} \mathrm{ha}^{-1}$ in Ivory coast, while in Ghana it reaches about $360 \mathrm{~kg} \mathrm{ha}^{-1}$.

Indonesia is the third-largest cacao producing country in the world after Ivory Coast and Ghana. Total cacao land of 1400000 ha in 2008 could contribute to the state of IDR $1800 \times 10^{6}$ [1]. Currently, cacao development areas in Indonesia include South

\footnotetext{
* Corresponding author: erfandani@umm.ac.id
} 
Sulawesi, West Sulawesi, Southeast Sulawesi, Central Sulawesi, West Papua, East Java, Lampung, West Sumatra, North Sumatra, and Aceh. Nationally, domestic cacao production reaches $700000 \mathrm{t} \mathrm{yr}^{-1}$, which is contributed the most by Sulawesi at around $70 \%$ [9]. However, increasing productivity and quality of cacao have experienced many obstacles, including pests and disease attacks on cacao plants.

One of the critical diseases in cacao plants is cacao pod rot caused by Phytophthora palmivora [(E. J. Butler) E. J. Butler]. The disease can reduce cacao production by $32.6 \%$ to $99 \%$. The distribution of this disease is widespread; its pathogenic diversity is also a threat to the decline in cacao production [14] Rates of $P$. palmivora attacks vary, more than $10 \%$ occur in Peninsular Malaysia and $80 \%$ to $90 \%$ in Cameroon. In Java, losses due to this disease reduce yields $33 \%$ to $50 \%$ [4]. The threat of rapid fruit rot disease develops in the cacao planting area, so first precautions need to be taken. In areas that have been infected with the disease can be controlled with biological agents that are environmentally friendly. The use of biological agents is very useful and positive in controlling fruit rot disease caused by $P$. palmivora [10]. According to [2], good biological agents are agents originating from areas where the disease in question is found. Therefore, in this study Trichoderma sp. indigenous East Java, Indonesia which is used as a biofungicide against pathogens, especially against $P$. Palmivora by in vitro testing.

Up to now, research used Trichoderma from the collection but not from the same location as the pathogen, so there is a possibility that there is a mismatch of environmental conditions that will affect the antagonistic ability of Trichoderma sp. itself in controlling P. palmivora. [12] Used Trichoderma sp. isolates from the collection; then it could suppress pathogens. [4] In vitro test of the three types of fungus Trichoderma were found on cacao plantations that Trichoderma sp., Trichoderma harzianum Rifai, and Trichoderma viride Pers., showed that $T$. viride was the most capable of inhibiting the growth of the fungus $P$. palmivora with the highest percentage of $71.95 \%$. Four antagonists [T. asperellum (SF04), T. virens (255C1), T. harzianum (THP) and T. longibrachiatum (4088)] were tested, All Trichoderma significantly $(p \leq 0.05)$ reduced the incidence and severity of disease. The 4088 ( $T$. longibrachiatum) isolate was the best controller agent of $P$. palmivora in postharvest [7]. The purpose of this study was to determine the effectiveness of Trichoderma sp. isolates from Jember and Trenggalek districts, East Java, Indonesia against causes of cacao pod rot (P. palmivora).

\section{Material and methods}

This study began in December 2018 until March 2019. This study used a Completely Randomized Design (CRD). CRD was arranged factorial with two factors. The first factor was the type of Trichoderma sp., the second factor was the type of P. palmivora, all treatment combinations were repeated three times. The treatments given were:

T: Trichoderma sp. (TR1: Trichoderma sp. origin of Suruh cacao plantation, Trenggalek, East Java, Indonesia; TR2: Trichoderma sp. origin of Karangan cacao plantation Trenggalek, East Java, Indonesia; JB1: Trichoderma sp. origin of PUSLITKAKAO cacao plantation, Jember, East Java, Indonesia; JB2: Trichoderma sp. origin of Banjarsari cacao plantation, Jember, East Java, Indonesia).

P: P. palmivora (P1: P. palmivora from Suruh cacao plantation, Trenggalek, East Java, Indonesia; P2: P. palmivora from Karangan cacao plantation, Trenggalek, East Java, Indonesia; P3: P. palmivora from Puslitkoka (Pusat Penelitian Kopi dan Kakao Indonesia - Indonesian Coffee and Cacao Research Institute) cacao plantation, Jember, East Java, Indonesia; P4: P . palmivora from Banjarsari cacao plantation, Jember, East Java, Indonesia). 


\subsection{The exploration of the fungus Trichoderma sp.}

Fungus Trichoderma sp. explored from cacao plantations in the Trenggalek and Jember districts, East Java, Indonesia. The point of taking soil was determined by the criteria for healthy cacao growing conditions (without symptoms of disease affecting the cacao plant). After the cacao plant was determined, it then digs up the soil as deep as $15 \mathrm{~cm}$ [3]. The isolation method of Trichoderma sp. used the dilution plate method.

\subsection{Exploration and Isolation of $\boldsymbol{P}$. palmivora pathogen}

P. palmivora was isolated from diseased cacao with blackish brown spots. The area of the pathogen exploration same as Trichoderma sp. exploration. The surface of the cacao fruit was sterilized with tissue with $70 \%$ alcohol. Approximately $0.5 \mathrm{~cm}$ of flesh was taken from the tissue, then planted into the Water Agar media and incubated for $4 \mathrm{~d}$ at room temperature. After $4 \mathrm{~d}$, the mycelia was purified on V8 agar medium $(200 \mathrm{~mL}$ of V8 juice, $800 \mathrm{~mL}$ of distilled water, $1 \mathrm{~g}$ of $\mathrm{CaCO}_{3}$ and $20 \mathrm{~g}$ of Agar)

\subsection{Identify fungi}

The fungus identification was carried out after the fungus grew the colony, the fungus Trichoderma sp. and P. palmivora were identified using a microscope so that the type of Trichoderma and P. palmivora was known by means of a colony in the observation of the microscope observed based on a journal or book so that the type of Trichoderma sp. as well as the identification of pathogens $P$. palmivora.

\subsection{Koch postulate test}

Healthy cacao pods were sterilized with sterile water, $0.5 \%$ Clorox, and then washed with sterile water. The surface of the cacao fruit is then injured using a needle and then inoculated with $P$. palmivora. Covered using a cotton cloth and taped. The disease incidence was determined based on the symptoms that appear. The results of the postula koch test were then isolated using V8 media and compared with origin $P$. palmivora isolate from exploration. If they showed the same characteristics, the postula koch test can prove the symptoms $P$. palmivora attack.

\subsection{Trichoderma sp. against pathogenic $P$. Palmivora}

Trichoderma sp. against $P$. palmivora cacao pod rot using a dual method on PDA media. Pieces of $P$. Palmivora isolates aged sevendai was placed with a distance of $2 \mathrm{~cm}$ from the edge of the petri dish then on the opposite side, was placed isolates of Trichoderma sp. with a range of $2 \mathrm{~cm}$ from the edge of the petri dish. The observation of the growth pathogen of $P$. Palmivora was carried out from one day to $7 \mathrm{~d}$ after the test.

The growth radius of $P$. palmivora was observed by measuring the growth of colonies of each fungus. Inhibition presentation using the Formula (1):

$$
\mathrm{Z}=(\mathrm{R} 1-\mathrm{R} 2) / \mathrm{R} 1 \times 100 \%
$$

where Z: Percentage of inhibition, R1: Radius of P. palmivora without Trichoderma sp. (Control), R2: $P$. palmivora radius with Trichoderma $\mathrm{sp.}$

The data were obtained then analyzed using the Analysis of Variance (ANOVA), if there were significantly different effects, further tests would be carried out using a $5 \%$ Tukeys. 


\section{Result and discussions}

\subsection{Exploration Trichoderma sp. results from plantation in Trenggalek Regency and Jember Regency, East Java, Indonesia}

Based on the exploration results of Trichoderma sp. from the cacao plantation area in Suruh District and Karangan District, Trenggalek Regency, East Java, Indonesia. Likewise, from the cacao plantations in PUSLITKAKAO and Banjaarsari District, Jember Regency, East Java, Indonesia each site was Trichoderma sp.

Microscopic appearance of Trichoderma sp. isolates, namely TR1, TR2 (Trenggalek), and JB1, JB2 (Jember) were green hyphae, short phyalid, greenish conidia, oval-shaped and there was also some conidia formed in clusters of light green on the surface of the conidiophore. Phyalid had a length of $\pm 11.1 \mu$ and conidiophore branches of $\pm 13.4 \mu$. There were many upright, branched conidiophores, vertically arranged branches, short thick phyalids, colony on potato Dextrose Agar media was dark green and round. The diameter of the colony reaches more than $9 \mathrm{~cm}$ within $5 \mathrm{~d}$. The characters from several isolates origin namely TR1, TR2, JB1, and JB2 showed the characteristics of T. harzianum $[15,6]$

$T$. harzianum is generally found in hot climates, the optimum temperature for growth of T. harzianum is $15{ }^{\circ} \mathrm{C}$ to $30{ }^{\circ} \mathrm{C}$, but the optimum growth is at $30{ }^{\circ} \mathrm{C}$ and for maximum temperatures of $30{ }^{\circ} \mathrm{C}$ to $36^{\circ} \mathrm{C}$. Normal growth of T. harzianum is at $\mathrm{pH} 3.7$ to 4.7 [13]

The benefits of $T$. harzianum was most often used in biological control because it has several comparative advantages compared to other organisms. A wide range of environments, mycoparasitic and able to compete in gaining space and producing antibiotics and enzymes that harm to the pathogens [13].

\subsection{P. palmivora exploration}

P. palmivora was isolated from diseased cacao with blackish-brown spots. Fruit exploration was carried out in cacao plantation areas where in the same area with Trichoderma sp. All isolates that were obtained characterized as $P$. palmivora. The characteristic of $P$. palmivora isolates a rounded edge colony. There were four forms of ovoid sporangia, limoniform, obturbinate, and obpyriform. Sporangium length $40 \mu \mathrm{m}$ to $62 \mu \mathrm{m}$ and width $28 \mu \mathrm{m}$ to $43 \mu \mathrm{m}$, have papillae, short pedicels, and simple simpodiabranching models. This criterion was as described by Stamps [13].

\subsubsection{Koch's postulates for identification test}

Tests were carried out on healthy cacao pods, then given $P$. palmivora pathogens (exploration results) and observed the symptoms of the pathogen as presented in Figure 1.
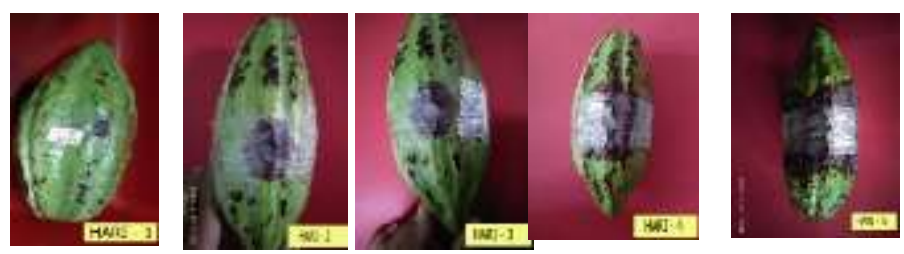

Fig. 1. Postulate test of fungus identification on healthy cacao

Based on Figure 1, P. palmivora disease attack on healthy cacao fruits showed the same symptoms as cacao pods affected by the disease. Koch postulates was used to prove the isolates obtained the causative agents of the observed disease symptoms. 
Koch's postulatewas also used as a method to identify fungi that cause signs of cacao pod rot (P.palmivora).

\subsection{Antagonistic test of Trichoderma sp. against $P$. palmivora}

An in vitro antagonist test was a way to evaluate the ability of antagonists (biological control agents) in a narrower scope and controlled environmental conditions (in vitro). The aim was to determine the potential or effectiveness of biological control agents in inhibiting the growth and development of pathogens [3]. The results of the antagonist test were presented in Table 1.

Based on the Tukey's test, the type of Trichoderma sp. TR1P1 showed the highest antagonicity $(78 \%)$ on $7 \mathrm{~d}$ observations against $P$ palmivora on PDA medium, It was significantly different from Trichoderma sp. JB2P3 (70 \%) on $7 \mathrm{~d}$ observations. The origin of $T$. harzianum isolate did not significantly influence the inhibition of $P$. palmivora from two different regions. The result of research was not in line with the results of the research of [2], that good controlling agents to control the disease were those from the same area with pathogen isolates. Antagonistic of all T. harzianum was no significant difference. It was likely due to the origin of the isolates being the same from the Java region, which has almost the same ambient temperature and humidity.

The difference in antagonism of Trichoderma sp. against P. palmivora, indicates the diversity of Trichoderma sp. who have been tested for their abilities as antagonists. This occurs a significant difference in the sporulation ability of each treatment type Trichoderma sp. following the results of Darmono's research [5], six isolates of Trichoderma sp. from the tested nature shows a difference in the ability to suppress P. palmivora.

According to [12] in general the mechanism of Trichoderma spp. in suppressing pathogens, namely as a micoparasitic and aggressive competitor. Initially, hypha Trichoderma spp. grow elongated, then convolve and penetrate the host fungal hyphae so that the host hyphae are vacuated, lysis, and finally destroyed. According to Harman [8] Trichoderma spp. penetrate the host cell wall with the help of cell wall degrading enzymes, namely chitinase, glucanase, and protease, then use the contents of the host hyphae as a food source. Trichoderma spp. also produce antibiotics such as gliotoxins and viridian when they penetrate cell wall.

Table 1. Antagonist test Trichoderma sp. to P. palmivora

\begin{tabular}{|c|c|c|c|c|c|c|c|}
\hline \multirow{2}{*}{ Treatment } & \multicolumn{7}{|c|}{ Disease intensity \% in day after inoculation (d) } \\
\cline { 2 - 8 } & 1 & 2 & 3 & 4 & 5 & 6 & 7 \\
\hline TR1P1 & $55 \mathrm{a}$ & $62 \mathrm{a}$ & $65 \mathrm{abc}$ & $66 \mathrm{ab}$ & $69 \mathrm{abc}$ & $72 \mathrm{ab}$ & $78 \mathrm{~b}$ \\
\hline TR1P2 & $44 \mathrm{a}$ & $53 \mathrm{a}$ & $68 \mathrm{c}$ & $69 \mathrm{~b}$ & $72 \mathrm{c}$ & $76 \mathrm{~b}$ & $76 \mathrm{ab}$ \\
\hline TR1P3 & $59 \mathrm{~b}$ & $62 \mathrm{a}$ & $65 \mathrm{abc}$ & $65 \mathrm{ab}$ & $70 \mathrm{bc}$ & $77 \mathrm{~b}$ & $77 \mathrm{ab}$ \\
\hline TR1P4 & $58 \mathrm{~b}$ & $58 \mathrm{a}$ & $66 \mathrm{abc}$ & $66 \mathrm{ab}$ & $68 \mathrm{abc}$ & $70 \mathrm{ab}$ & $75 \mathrm{ab}$ \\
\hline TR2P1 & $48 \mathrm{a}$ & $57 \mathrm{a}$ & $65 \mathrm{abc}$ & $67 \mathrm{ab}$ & $69 \mathrm{abc}$ & $72 \mathrm{ab}$ & $75 \mathrm{ab}$ \\
\hline TR2P2 & $52 \mathrm{a}$ & $59 \mathrm{a}$ & $67 \mathrm{bc}$ & $67 \mathrm{ab}$ & $70 \mathrm{bc}$ & $74 \mathrm{ab}$ & $76 \mathrm{ab}$ \\
\hline TR2P3 & $47 \mathrm{a}$ & $56 \mathrm{a}$ & $65 \mathrm{abc}$ & $65 \mathrm{ab}$ & $68 \mathrm{abc}$ & $73 \mathrm{ab}$ & $75 \mathrm{ab}$ \\
\hline TR2P4 & $46 \mathrm{a}$ & $55 \mathrm{a}$ & $65 \mathrm{abc}$ & $66 \mathrm{ab}$ & $66 \mathrm{abc}$ & $72 \mathrm{ab}$ & $72 \mathrm{ab}$ \\
\hline JB1P1 & $52 \mathrm{a}$ & $62 \mathrm{a}$ & $66 \mathrm{abc}$ & $68 \mathrm{ab}$ & $70 \mathrm{bc}$ & $74 \mathrm{ab}$ & $77 \mathrm{ab}$ \\
\hline JB1P2 & $48 \mathrm{a}$ & $56 \mathrm{a}$ & $63 \mathrm{abc}$ & $66 \mathrm{ab}$ & $66 \mathrm{abc}$ & $75 \mathrm{ab}$ & $75 \mathrm{ab}$ \\
\hline JB1P3 & $45 \mathrm{a}$ & $55 \mathrm{a}$ & $62 \mathrm{abc}$ & $65 \mathrm{ab}$ & $65 \mathrm{abc}$ & $72 \mathrm{ab}$ & $74 \mathrm{ab}$ \\
\hline JB1P4 & $42 \mathrm{a}$ & $58 \mathrm{a}$ & $60 \mathrm{abc}$ & $63 \mathrm{ab}$ & $64 \mathrm{abc}$ & $74 \mathrm{ab}$ & $74 \mathrm{ab}$ \\
\hline JB2P1 & $44 \mathrm{a}$ & $55 \mathrm{a}$ & $58 \mathrm{a}$ & $62 \mathrm{a}$ & $64 \mathrm{abc}$ & $73 \mathrm{ab}$ & $75 \mathrm{ab}$ \\
\hline
\end{tabular}

(Continued on next page) 
Table 1. Continued

\begin{tabular}{|c|c|c|c|c|c|c|c|}
\hline \multirow{2}{*}{ Treatment } & \multicolumn{7}{|c|}{ Disease intensity \% in day after inoculation (d) } \\
\cline { 2 - 8 } & 1 & 2 & 3 & 4 & 5 & 6 & 7 \\
\hline JB2P2 & $55 \mathrm{a}$ & $56 \mathrm{a}$ & $58 \mathrm{a}$ & $62 \mathrm{a}$ & $62 \mathrm{ab}$ & $70 \mathrm{ab}$ & $72 \mathrm{ab}$ \\
\hline JB2P3 & $53 \mathrm{a}$ & $55 \mathrm{a}$ & $63 \mathrm{abc}$ & $63 \mathrm{a}$ & $63 \mathrm{ab}$ & $69 \mathrm{a}$ & $70 \mathrm{a}$ \\
\hline JB2P4 & $55 \mathrm{a}$ & $56 \mathrm{a}$ & $65 \mathrm{abc}$ & $65 \mathrm{ab}$ & $65 \mathrm{a}$ & $69 \mathrm{a}$ & $74 \mathrm{ab}$ \\
\hline BNJ 5 \% & 6.021 & 6.35 & 6.98 & 7.046 & 7.24 & 7.62 & 7.93 \\
\hline & $* *$ & $* *$ & $* *$ & $* *$ & $* *$ & $* *$ & $* *$ \\
\hline
\end{tabular}

Note: Values followed by the same letter in the same column in the Tukey's test at a level of $5 \%$ show very significant different

TR1: Isolate Trichoderma sp. Trenggalek Regency in Suruh District, East Java, Indonesia; TR2: Isolate Trichoderma sp. Trenggalek Regency in Karangan District, East Java, Indonesia; JB1: Isolate Trichoderma sp. Jember Regency in PUSLITKAKAO Jember, East Java, Indonesia; JB2: Trichoderma sp. Jember Regency in the District of Banjarsari, East Java, Indonesia; P1: P. palmivora from the Suruh cacao plantation in Trenggalek Regency, East Java, Indonesia; P2: P. palmivora from Karangan cacao plantation in Trenggalek Regency, East Java, Indonesia; P3: P . palmivora from PUSLITKAKAO cacao plantation in Jember Regency, East Java, Indonesia; P4: P . palmivora from Banjarsari cacao plantation in Jember Regency, East Java, Indonesia.

Control mechanisms with biological agents against plant pathogenic fungi are generally divided into three types, firstly competition for growth sites and nutrition, secondly antibiosis, and thirdly parasitism [8]. The mechanism of parasitism is an interesting phenomenon that plays an essential role in the process of biological control. Trichoderma spp. usually use this mechanism with other, namely competition and antibiosis.

\section{Conclusions}

Antagonistic test results, isolates of Trichoderma sp. very effective in inhibiting the growth of P. palmivora. Isolates from Trenggalek district, Suruh sub-district (TR1P1) were the most effective isolates because they can inhibit the growth of $P$. palmivora by $78 \%$, and a significant difference from Trichoderma sp. JB2P3 of $70 \%$

\section{References}

1. B. Scanu, B.T. Linaldeddu, A. Deidda, T. Jung. PLoS One. 10,12:1-24(2015). https://doi.org/10.1371/journal.pone.0143234

2. Alfizar, Marlina, F. Susanti. Floratek. 8,1:45-51(2013). [in Bahasa Indonesia]. http://www.jurnal.unsyiah.ac.id/index.php/floratek/article/download/860/799

3. U.S. Hastuti, I. Rahmawati. J. Pure Appl. Chem. Res. 5,3:178-181(2016). https://doi.org/10.21776/ub.jpacr.2016.005.03.260

4. R. Sriwati, T. Chamzurni, L. Soesanto, M. Munazhirah. Agrivita. 41,1:175-182(2019). https://doi.org/10.17503/agrivita.v41i1.2146

5. T.W. Darmono. Menara Perkebunan. 62,2:2530(1994). [in Bahasa Indonesia]. https://scholar.google.co.id/scholar?hl=id\&as_sdt=0\%2C5\&q=Kemampuan+beberapai solate + Trichoderma + spp. + dalam + menekan + inokulum + Phytophthora + sp. + di + dalam $+j$ aringan+buah+kakao\&btnG $=$

6. D.L. Taylor, R.L. Sinsabaugh. The Soil Fungi: Occurrence, Phylogeny, and Ecology, Elsevier, USA (2015). p.77-109. https://doi.org/10.1016/b978-0-12-415955-6.00004-9

7. T.A.S. de Oliveira, L.E.B. Blum, E.A.A. Duarte, E.D.M.N. Luz. Biosci. J. 34,6: 1513-1521(2018). https://doi.org/10.14393/bj-v34n6a2018-39548

8. G.E. Harman. The American Phytopathological Society. 96,2:190-194(2006). https://doi.org/10.1094/PHYTO-96-0190 
9. A.G. Maulana, A. Permana. Atasi impor kakao, pemerintah didesak remajakan tanaman. [in Bahasa Indonesia]. [Online] from

http://www.m.bisnis.com/industri/read/20150313/99/411481/atasi-imporpemerintahdidesak-remajakan-tanaman.com (2016) [Acessed on 10 August 2020].

10. I.Y. Opoku, A.Y. Akrofi, A.A. Appiah. Eur. J. Plant Pathol. 117: 167-175(2007). https://doi.org/10.1007/s10658-006-9082-8

11. A. Singh, M. Shahid, M. Srivastava, S. Pandey, A. Sharma, V. Kumar. Virol. Mycol. 3,1:1-7(2014).

https://www.researchgate.net/publication/270564856_Optimal_Physical_Parameters_f or_Growth_of_Trichoderma_species_at_Varying_pH_Temperature_and_Agitation

12. A.O. Nwankiti, VI. Gwa. Trends Tech. Sci. Res. 1,1(2018).

https://scholar.google.co.id/scholar?hl=id\&as sdt $=0 \% 2 \mathrm{C} 5 \& \mathrm{q}=$ Evaluation + of + Antagon istic + Effect + of + Trichoderma + Harzianum + against + Fusarium + oxysporum + causal + Age $\underline{\text { nt }+ \text { of }+ \text { White }+ \text { Yam }+\% 28 \text { Dioscorearotundata }+ \text { poir } \% 29+\text { Tuber }+ \text { Rot\&btnG }=}$

13. H.H. Ho. J. Bacteriol. Mycol. Open Access. 6,1:40-45(2018). https://doi.org/10.15406/jbmoa.2018.06.00174

14. K. Nidhina, K.M. Sharadraj, V.H. Prathibha, V. Hegde, K.P. Gangaraj. Vegetos. 29,2:19-26(2016).

https://scholar.google.co.id/scholar?hl=id\&as_sdt=0\%2C5\&q=Antagonistic + activity $+_{\mathrm{o}}$ f+Trichoderma+Spp.+to+Phytophthora+infecting + plantation+crops + and + its + beneficia 1+effect + on + germination + and + plant + growth + promotion $\&$ btnG $=$

15. T. Watanabe. Pictorial Atlas of Soil and Seed Fungi, 3rd ed. Boca Raton: CRC Press. (2010). p. 426. https://doi.org/10.1201/ebk1439804193 